\title{
Municipal landfill leachate characteristics and feasibility of retrofitting existing treatment systems with deammonification - A full scale survey
}

Ehsan Mohammad-pajooh", Dirk Weichgrebe, Graham Cuff

* Corresponding author.

E-mail addresses: pajooh@isah.uni-hannover.de (E. Mohammad-pajooh), weichgrebe@isah.unihannover.de (D. Weichgrebe), cuff@isah.uni-hannover.de (G. Cuff)

Institute for Sanitary Engineering and Waste Management, Leibniz University Hannover, Appelstr. 9a, 30167 Hannover, Germany

\begin{abstract}
Leachate characteristics, applied technologies and energy demand for leachate treatment were investigated through survey in different states of Germany. Based on statistical analysis of leachate quality data from 2010 to 2015, almost half of the contaminants in raw leachate satisfy direct discharge limits. Decrease in leachate pollution index of current landfills is mainly related to reduction in concentrations of certain heavy metals $(\mathrm{Pb}, \mathrm{Zn}, \mathrm{Cd}, \mathrm{Hg}$ ) and organics (biological oxygen demand $\left(\mathrm{BOD}_{5}\right)$, chemical oxygen demand (COD), and adsorbable organic halogen (AOX)). However, contaminants of concern remain $\mathrm{COD}$, ammonium-nitrogen $\left(\mathrm{NH}_{4}-\mathrm{N}\right)$ and $\mathrm{BOD}_{5}$ with average concentrations in leachate of about 1850, 640, and $120 \mathrm{mg} / \mathrm{L}$ respectively. Concentrations of COD and $\mathrm{NH}_{4}-\mathrm{N}$ vary seasonally, mainly due to temperature changes; concentrations during the first quarter of the year are mostly below the annual average value. Electrical conductivity (EC) of leachate may be used as a time and cost saving alternative to monitor sudden changes in concentration of these two parameters, due to high correlations of around 0.8 with both $\mathrm{COD}$ and $\mathrm{NH}_{4}-\mathrm{N}$ values which are possibly due to low heavy metal concentrations in leachate. The decreased concentrations of heavy metals and $\mathrm{BOD}_{5}$ favor the retrofitting of an existing biological reactor (nitrification/denitrification) with the deammonification process and post denitrification, as this lowers average annual operational
\end{abstract}


cost (in terms of energy and external carbon source) and $\mathrm{CO}_{2}$ emission by $€ 25,850$ and 15,855 $\mathrm{kg}$ $\mathrm{CO}_{2, \mathrm{eq}}$ respectively.

Keywords: Leachate characteristics; Leachate treatment; Deammonification; Anammox; Energy efficiency; Technology acceptance

\section{List of abbreviations:}

Anammox, anaerobic ammonium oxidation; AnAOB, anaerobic ammonium-oxidizing bacteria; AOX, adsorbable organic halogen; $\mathrm{BOD}_{5}$, biological oxygen demand; $\mathrm{COD}$, chemical oxygen demand; $\mathrm{C} / \mathrm{P}$, chemical/physical; DN, denitrification; DO, dissolved oxygen; DWD, Deutsche Wetterdienst (/Germany’s National Meteorological Services); EC, electrical conductivity; LPI, leachate pollution index; MAP, magnesium ammonium phosphate (/struvite); MBBR, moving bed bioreactor; MBR, membrane bioreactor; MBT, mechanical biological treatment; N/DN, nitrification/denitrification; $\mathrm{NH}_{4}-\mathrm{N}$, ammonium-nitrogen; $\mathrm{PN}$, partial nitritation; RO, reverse osmosis; SBR, sequencing batch reactor; TDS, total dissolved solids; UF, ultrafiltration; UN-SDGs, United Nations sustainable development goals.

\section{Introduction}

One of the potential environmental problems caused by decomposition of wastes in a landfill is production of leachate, which originates from percolated rainwater, waste decomposition runoff, and the water content of waste itself (Renou et al., 2008). Characteristics of the produced leachate depend on, among other factors, degree of stabilization of deposited waste, waste collection system, type and composition of deposited waste (Fitzke et al., 2013), solubility of waste constituents (Salem et al., 2008), location and hydrological factors (Chu et al., 1994), as well as waste compaction, landfill design and operation in addition to cultural differences (Baig et al., 1999). 
Unstabilized waste (also referred to as untreated waste) leads to higher leachate pollution loads compared to stabilized waste (also referred to as pre-treated waste) as it contains a higher portion of biodegradable organic content, which then undergoes decomposition within the landfill. Leachate quality from landfills varies greatly over time, and can be categorized either as a function of age of the landfill or more precisely as a function of phases of the landfill, which are categorized into: (1) aerobic phase, (2) anaerobic acid phase (i.e. organic acid production), (3) initial/intermediate/stable methanogenic phase (i.e. methane and carbon dioxide production), and (4) final aerobic phase (Heyer et al., 2001; Kjeldsen et al., 2002). These phases are distinguished based on changes in the concentrations of principle contaminants (mainly organics, nitrogen, and heavy metals) and gas production and quality.

One way to reduce landfill emissions (leachate and gas) is to remove the impurities and biodegradable organic matters (through stabilization) from the waste before landfilling. This approach is known as waste pre-treatment and has been widely applied in Germany since 2005. Pre-treatment of waste is performed at mechanical biological treatment plants (MBT plants) in which waste is initially processed through a mechanical stage in which resources or impurities such as metals and plastics are recovered or removed. Next, a biological stage which includes aerobic and/or anaerobic stabilization of waste is carried out for weeks prior to landfilling. The type and duration of the MBT process affects the quality of pre-treated deposited waste (Siddiqui et al., 2012) and as a result the leachate pollution. Therefore, leachate quality from currently operating landfills depends mainly on the amount and degree of stabilization of deposited waste, and whether external wastewater streams (i.e. process water from MBT, external leachate or concentrate discharged from other landfills) are mixed with existing leachate from the landfill.

After MBT, organic concentrations are reduced significantly; however nitrogen concentrations in waste remain at high level (Tran et al., 2013). The remaining ammonium nitrogen will be contained in the leachate of landfilled waste, and can be removed through conventional treatment processes such as nitrification/denitrification (N/DN), air stripping, and struvite precipitation, or more advanced biological techniques such as nitritation/denitritation, deammonification (a process of partial nitritation 
(PN) and anaerobic ammonium oxidation (anammox) in moving bed bioreactor (MBBR) configuration), or membrane-based processes such as a membrane bioreactor (MBR) integrated with an anoxic tank. Among all the advanced techniques for $\mathrm{NH}_{4}-\mathrm{N}$ removal, struvite precipitation (also known as magnesium ammonium phosphate (MAP) precipitation) and deammonification have the highest energy savings potential. The main advantages of the deammonification process compared to conventional N/DN are the reductions of 1) aeration/energy costs, 2) external carbon source requirement, and 3) sludge production (Christensson et al., 2013; Jenkins and Wanner, 2014). The deammonification process is well suited for landfill leachate treatment, and was first implemented in the early 1990s at a landfill leachate treatment plant in Mechernich, Germany (Hippen et al., 1997). During deammonification, initially 50 to $60 \%$ of influent ammonia is oxidized to nitrite (this stage is also known as partial nitritation step (WERF, 2014)); the remaining ammonia is then converted together with nitrite by anaerobic ammonium-oxidizing bacteria (AnAOB) into dinitrogen gas and small amounts of nitrate (Rosenwinkel and Cornelius, 2005). Full-scale PN/Anammox plants with different configurations and reactor types (i.e. SBR, MBBR/deammonification, Granular) and their issues (e.g. foaming, $\mathrm{NH}_{4}-\mathrm{N}, \mathrm{NO}_{2}-\mathrm{N}$, and $\mathrm{NO}_{3}-\mathrm{N}$ build up) and countermeasures were recently surveyed by Lackner et al. (2014).

Despite the advantages of deammonification, most of the current leachate treatment plants in Germany are mainly founded on conventional treatment processes, typically a combination of nitrification and denitrification (for organics and nitrogen removal) with a wide range of different chemical/physical (C/P) processes for heavy metals and COD removal. The range of C/P processes vary depending on the targets of treatment (i.e. direct discharge or indirect discharge) from simple techniques such as chemical precipitation to more sophisticated techniques like side-stream ozonation and/or membrane technologies such as ultrafiltration (UF) and reverse osmosis (RO). These technologies are then coupled at a final stage with activated carbon to remove remaining heavy metals, adsorbable organic halogen (AOX), and non-biodegradable COD prior to discharge (Wiszniowski et al., 2006)). 
The current research aimed to investigate: (1) the effect of pretreatment to reduce the overall leachate contamination, (2) seasonal leachate quality fluctuations, and (3) whether the deammonification process is a cost effective alternative to current leachate treatment processes.

\section{Materials and Methods}

Seventy nine landfills were surveyed in Germany and the rate of response varied greatly based on the type of requested data. The response rate for leachate characteristic data, implemented technologies for leachate treatment, treatment cost, and energy consumption were $32 \%, 68 \%, 30 \%$, and $6 \%$ respectively. The number of responded landfills with respect to the data type is shown in Fig. 1. In this study only data related to leachate characteristics are discussed in detail.

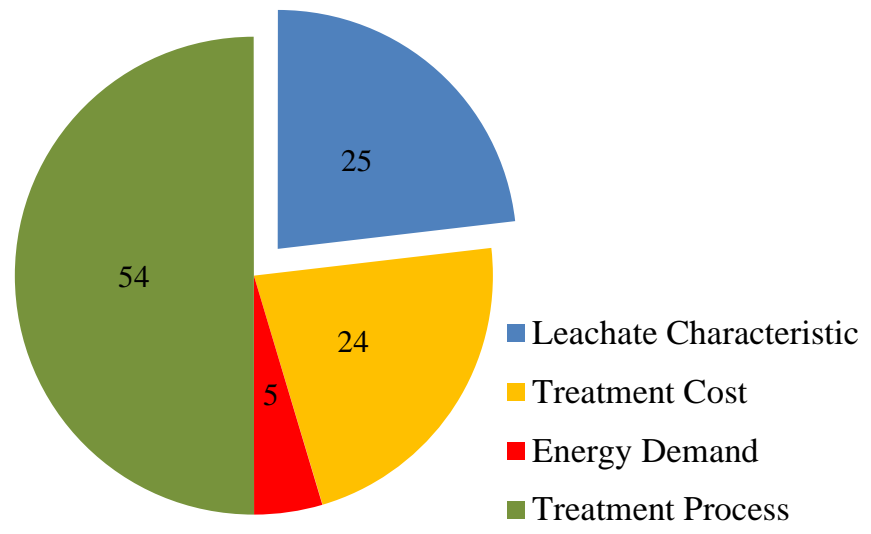

Fig. 1. Number of responded landfill with respect to the requested data type

The first aim of this study was to investigate leachate quality from current landfills in Germany, and to identify to what extent this leachate quality has changed over recent years, and also seasonally. To meet this objective, waste from pre-2005 deposits (before pre-treatment was standard) was assumed, after five years, to be similarly stabilized to that of pre-treated waste. This allowed for the use of 20102015 as the representative sample when examining leachate quantity and quality data. To investigate the overall changes in leachate quality a leachate pollution index (LPI) was developed. The concept of LPI formulation was proposed by Kumar and Alappat (2005) through questionnaires and rating parameters. However, in the current study, the LPI utilizes previous measurements by Kruse (1994), who investigated leachate quality of 33 landfills in Northern Germany in 1994. Therefore, the LPI in 
the study represents the changes in ratios of sum parameters and main pollutants (i.e. key pollutants recorded during 1994-2015) and is obtained through the following formulae:

$\mathrm{LPI}_{\mathrm{M}, \mathrm{A}}=\sum_{\mathrm{i}=1}^{\mathrm{n}}\left(\mathrm{P}_{\mathrm{i}, \mathrm{M}} / \mathrm{P}_{\mathrm{i}, \mathrm{A}}\right) ; \mathrm{LPI}_{\mathrm{C}, \mathrm{A}}=\sum_{\mathrm{i}=1}^{\mathrm{n}}\left(\mathrm{P}_{\mathrm{i}, \mathrm{C}} / \mathrm{P}_{\mathrm{i}, \mathrm{A}}\right) ; \mathrm{LPI}_{\mathrm{C}, \mathrm{M}}=\sum_{\mathrm{i}=1}^{\mathrm{n}}\left(\mathrm{P}_{\mathrm{i}, \mathrm{C}} / \mathrm{P}_{\mathrm{i}, \mathrm{M}}\right)$

in which $P_{i}$ is pollutant variable, $n$ is number of pollutant variables, $A, C$, and $M$ represent pollutant variable concentrations at acidic, methanogenic, and current phase respectively.

To determine seasonal variations in leachate quality, changes in concentration of main parameters (COD, $\mathrm{NH}_{4}-\mathrm{N}, \mathrm{NO}_{3}-\mathrm{N}$ ) were measured on a quarterly basis. Primary data (raw data) and secondary data were collected from an onsite meteorological station of a landfill in Germany and Germany's National Meteorological Services (Deutsche Wetterdienst), respectively, to identify meteorological influences.

The second objective of this study was to investigate how leachate treatment technologies, energy demand and total treatment costs differ among the landfills in Germany, and as a result identify an energy efficient treatment process or propose a better alternative technology based on gathered data. To meet the second objective, landfill operators were requested to provide details of leachate treatment processes (i.e. type and sequence of implemented technologies and influent quality data prior to every treatment step), energy consumption of onsite treatment processes (through data logger, inventories, and/or energy audits), as well as costs associated with leachate treatment and concentrate management.

\section{Results and discussion}

\subsection{Leachate production in Germany: quantity, storage, and quality}

Estimation of leachate generation rate and annual leachate volume are crucial to design a treatment system with sufficient hydraulic capacity and to allow its future expansion with minimal reinvestment, respectively. Leachate flow rates from landfills in northern Germany are often equal to between 12 to $22 \%$ of precipitation (Heyer et al., 2001), and annual leachate volumes (with internal

leachate treatment) range between $12,000 \mathrm{~m}^{3}$ to $52,150 \mathrm{~m}^{3}$. Table 1 lists the ranges and average 
leachate volumes of 17 landfills during 2010 to 2015, categorized in daily, weekly, monthly, and yearly terms.

Table 1

Range of generated leachate quantity during year 2010 to 2015 from seventeen landfills.

\begin{tabular}{|c|c|c|c|c|c|c|c|}
\hline \multicolumn{2}{|c|}{ Yearly $\left(\mathrm{m}^{3}\right)$} & \multicolumn{2}{|c|}{ Monthly $\left(\mathrm{m}^{3}\right)$} & \multicolumn{2}{|c|}{ Weekly $\left(\mathrm{m}^{3}\right)$} & \multicolumn{2}{|c|}{ Daily $\left(\mathrm{m}^{3}\right)$} \\
\hline Average & Range & Average & Range & Average & Range & Average & Range \\
\hline 25400 & $12000-52150$ & 2117 & $284-6440$ & 488 & $170-1840$ & 70 & $25-280$ \\
\hline
\end{tabular}

After generation, the leachate is captured and then drained to storage tank(s) with a capacity range of 1500 to $4500 \mathrm{~m}^{3}$. Storage tanks provide equalization and buffering, and capacity is designed based on daily flow; by considering average daily flow and capacity of storage tank of each landfill, a safety factor (peak factor; $\mathrm{P}_{\mathrm{d}}$ ) of 29 to 42 is derived. Thus storage is sufficient to hold about a month's worth of generated leachate volume. Peak factor for a storage design is site specific; however, design may also be influenced by consultant experience. The site specific aspect refers to differences in terms of landfill capacity, waste quality (for example, waste with low organic content may absorb less water and result in higher infiltration rate), weather conditions (e.g. type and intensity of precipitation), landfill design (e.g. impermeable vs. permeable sealing) and operational mode (e.g. recirculation of leachate, number of open sections), as well as capacity of the leachate treatment plant. Based on data of leachate quantity and treatment capacity, two formulas are used for estimation of required $\left(\mathrm{Q}_{\mathrm{st}}\right)$ and minimum $\left(\mathrm{Q}_{\mathrm{st} \text { min }}\right)$ storage capacity:

$\mathrm{Q}_{\mathrm{st}}=\left(\mathrm{P}_{\mathrm{d}} \times \mathrm{Q}_{\mathrm{d}}\right)+(170 \times \mathrm{n})$

$\mathrm{Q}_{\mathrm{st}, \text { min }}=\left(\mathrm{P}_{\mathrm{d}, \min } \times \mathrm{Q}_{\mathrm{d}}\right)+(170 \times \mathrm{n})$

In these formulas, $\mathrm{Q}_{\mathrm{d}}$ represents an average daily flow rate of leachate, $\mathrm{P}_{\mathrm{d}}$ is the peak factor or safety factor which lies between 29 to $42, P_{d, \min }$ is a critical peak factor (=9), and n represents the number of external landfills from which leachate will be received. The critical peak factor of 9 is defined based on summation of minimum peak factors of 5.5 and 3.5 which relate to capacity of leachate treatment processes and effects of seasonal variations, respectively. The minimum factor of 5.5 is the lowest 
ratio obtained by dividing the storage tank capacity over maximum treatment capacity for different landfills; the role of this factor may be critical in case of failure or for maintenance of the system. The value of 3.5 is derived from analysis of maximum possible daily fluctuation in leachate volume; this factor may be critical during wet weather conditions. The value of 170 is a reserve of $170 \mathrm{~m}^{3}$ per month to facilitate leachate delivery from external landfills; this value is derived from maximum leachate volumes of four landfills which treat their leachate externally.

Once the leachate is stored it should be characterized. Leachate characteristics are strongly related to waste decomposition (Kjeldsen et al., 2002). As pre-treated waste has lower biodegradation potential, the resulting leachate is expected to be less polluted and less variable over time. To evaluate transitions in leachate quality due to the introduction of waste pre-treatment steps, the overall changes in leachate quality should be represented quantitatively; this is done by defining a leachate pollution index (LPI), which is obtained through changes in concentrations of 20 leachate quality parameters. Leachate quality parameters from acid (A) and methanogenic (M) phases represent average values among 33 landfills in Northern Germany; these data were adapted from a study by Kruse (1994). However, data from the current (C) phase refers to leachate quality from 2010 to 2015 of 25 landfills in different states of Germany, which were collected through survey in this study.

As shown in Fig. 2, if the leachate quality from the acidic phase is considered as a reference point and compared against leachate quality from methanogenic and current phase, then the LPI is reduced in the methanogenic and current phase by 4.5 (i.e. 15.5 from 20) and 6.2 (i.e. 13.8 from 20) respectively. Similarly if the methanogenic phase is taken as a reference point, and changes in leachate quality parameters of the current phase are compared against changes of the same parameters in the methanogenic phase $(\mathrm{C} / \mathrm{M})$, then pre-treatment of deposited waste reduces the LPI by another 20\%. This reduction in LPI by 4 (16 from 20) is due to significant reduction in concentration of contaminants such as iron (total), lead, and zinc, and 50 to $70 \%$ reduction in organics $\left(\mathrm{BOD}_{5}\right.$, COD, adsorbable organic halogen or AOX) and heavy metals such as cadmium and mercury. Further detail about data and calculation of LPI are available in a supplementary appendix. 


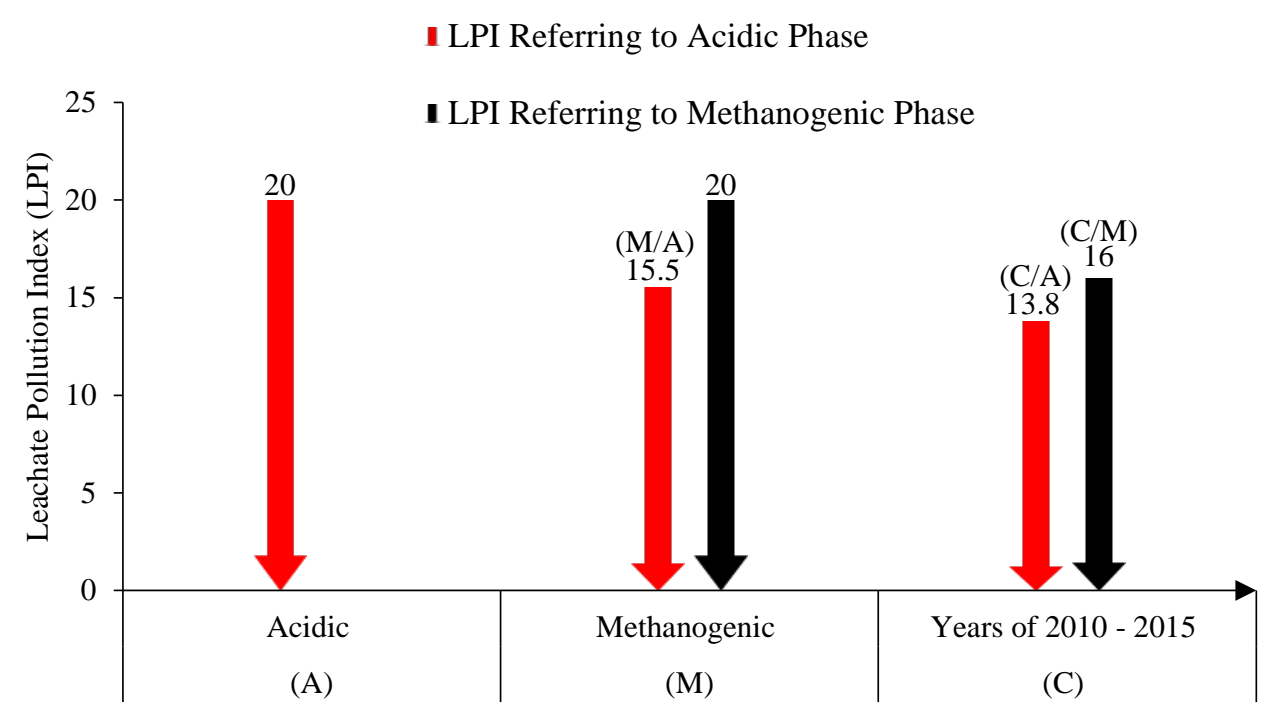

Fig. 2. Transition in overall leachate quality due to introduction of waste pre-treatment

Ranges of leachate contaminant concentrations based on monthly data from 2010 to 2015 are plotted in Fig. 3. This figure also summarizes arithmetic mean, weighted average, 95th percentile, and maximum range for each contaminant. By considering mean value (or even weighted average) as a typical concentration value, then predominant contaminants in current leachate are mostly likely to be COD, $\mathrm{Cl}, \mathrm{Na}, \mathrm{K}$, and $\mathrm{NH}_{4}-\mathrm{N}$, while most heavy metal concentrations are insignificant. 


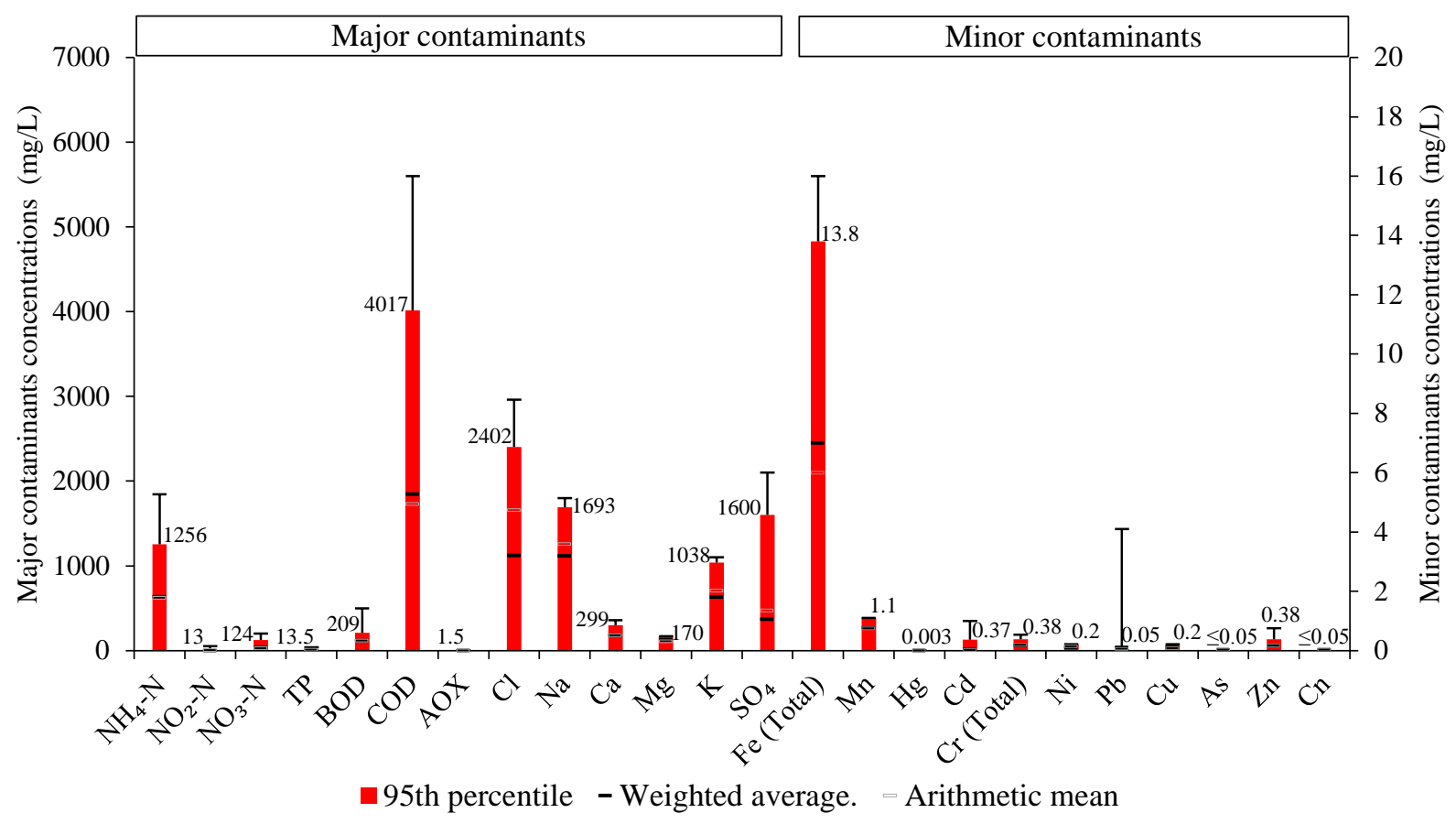

Fig. 3. Leachate quality from German landfills during 2010 to 2015.

\subsection{Effects of seasonal variations}

Leachate contaminant concentrations vary over different phases at a landfill (e.g. acidic, methanogenic) (Kjeldsen et al., 2002) but also over different seasons of the year (Chu et al., 1994). However, in the case of pre-treated waste, the changes in both quantity and quality of leachate are mainly influenced by seasonal variation rather than landfill phase, since pre-treated waste has already undergone stabilization reactions during pre-treatment.

In this study, variation of leachate quality is discussed in terms of changes in electrical conductivity (EC), COD, $\mathrm{NH}_{4}-\mathrm{N}$, and $\mathrm{NO}_{3}-\mathrm{N}$ concentrations. Electrical conductivity reflects concentration of dissolved inorganic matter (Tatsi and Zouboulis, 2002); as it is a sum parameter, changes in EC may form a general representation of processes related to the inorganic fraction of deposited waste and as a result with leachate quality. As shown in Fig. 4 the maximum yearly fluctuation of EC in three landfills is up to $4000 \mu \mathrm{S} / \mathrm{cm}$, however the ratio of chloride (in $\mathrm{mg} / \mathrm{L}$ ) to electrical conductivity (in $\mu \mathrm{S} / \mathrm{cm}$ ) in these landfills is relatively stable, remaining at 0.1 for landfill $\mathrm{B}$ and $\mathrm{C}$ and 0.14 to 0.19 for landfill A over 4 years. 


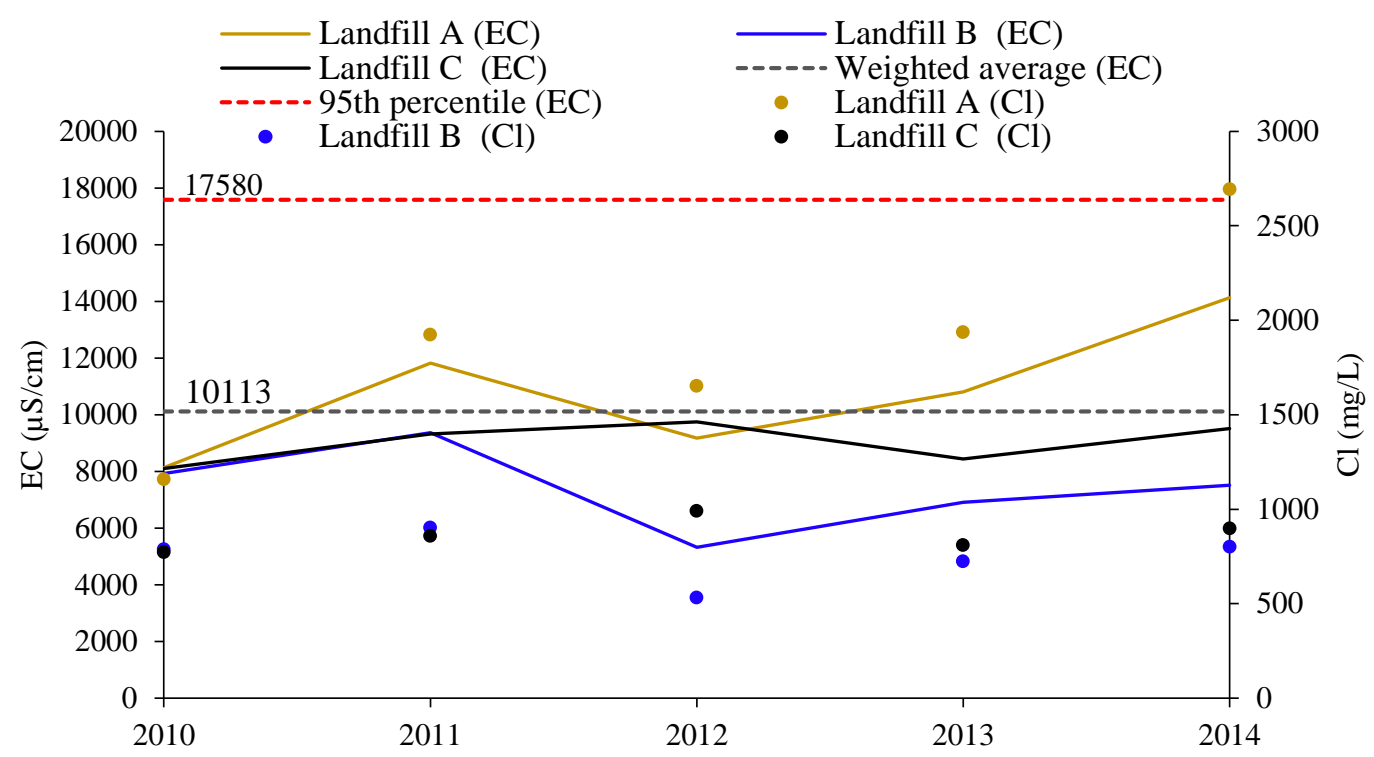

Fig. 4. Variation of electrical conductivity of leachate among three different landfills from 2010 to 2014.

Understanding long term fluctuation patterns of produced contaminants is useful for design and dimensioning of a new system or optimization of an existing treatment process. Therefore fluctuations in $\mathrm{COD}, \mathrm{NH}_{4}-\mathrm{N}$ and $\mathrm{NO}_{3}-\mathrm{N}$ concentrations among three different landfills which have continuously recorded these values during 2010 to 2014 have been shown in Fig. 5. According to the figure, contamination level decreases in the first quarter of the year, and increases in the second and third quarters. The fluctuation pattern is also demonstrated in terms of frequencies at which an average quarterly value falls below the yearly average value. An example of this is presented in Table 2 which shows that concentrations of COD and $\mathrm{NH}_{4}-\mathrm{N}$ are most likely to be below the yearly average value during the first quarter of the year, as it occurs in about $90 \%$ and $80 \%$ of cases for COD and $\mathrm{NH}_{4}-\mathrm{N}$ respectively. In contrast, $\mathrm{NO}_{3}-\mathrm{N}$ concentration and $\mathrm{NO}_{3}-\mathrm{N} / \mathrm{NH}_{4}-\mathrm{N}$ ratio may increase during this quarter. The highest quarterly fluctuations observed in all years for $\mathrm{COD}, \mathrm{NH}_{4}-\mathrm{N}$, and $\mathrm{NO}_{3}-\mathrm{N}$ were +1698 mg/L, +991 mg/L and -165 mg/L respectively. 
Parameter concentrations in first quarter of the year, relative to yearly average, and maximum range of fluctuation in concentration of these parameters in all quarters.

\begin{tabular}{|c|c|c|c|c|c|c|}
\hline \multirow[t]{3}{*}{ Parameter } & \multirow{3}{*}{$\begin{array}{l}\text { Number of } \\
\text { observations } \\
\text { (from 2010-2014) }\end{array}$} & \multicolumn{3}{|c|}{ Frequency that Q1 was (below) or above } & \multirow[t]{3}{*}{ Sum } & \multirow{3}{*}{$\begin{array}{l}\text { Ranges of } \\
\text { fluctuations in all } \\
\text { quarters of years }\end{array}$} \\
\hline & & \multicolumn{3}{|c|}{ yearly average } & & \\
\hline & & Landfill 1 & Landfill 2 & Landfill 3 & & \\
\hline COD (mg/L) & 15 & (5) & (4) & (5) & (14) & (946) to 1698 \\
\hline $\mathrm{NH}_{4}-\mathrm{N}(\mathrm{mg} / \mathrm{L})$ & 15 & (5) & (4) & (3) & (12) & (467) to 991 \\
\hline $\mathrm{NO}_{3}-\mathrm{N}(\mathrm{mg} / \mathrm{L})$ & 15 & 4 & 3 & 2 & 9 & (165) to 113 \\
\hline $\mathrm{NO}_{3}-\mathrm{N} / \mathrm{NH}_{4}-\mathrm{N}(-)$ & 15 & 5 & 3 & 4 & 12 & $(0.31)$ to 0.34 \\
\hline
\end{tabular}

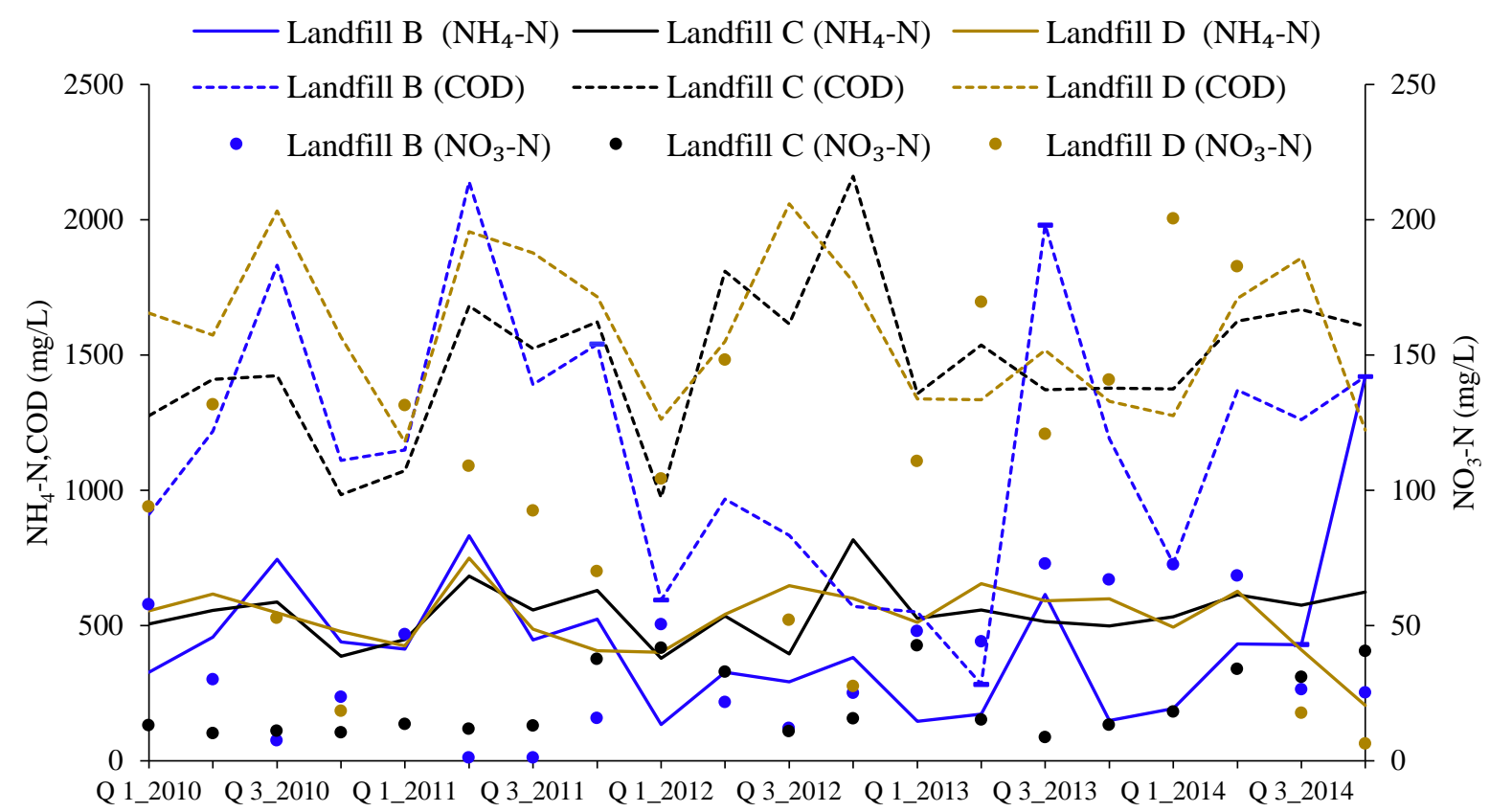

Fig. 5. Fluctuation of $\mathrm{NH}_{4}-\mathrm{N}, \mathrm{NO}_{3}-\mathrm{N}$ and $\mathrm{COD}$ over studied time period.

To further evaluate the individual effects of temperature and precipitation on changes in COD and $\mathrm{NH}_{4}-\mathrm{N}$ concentrations, precipitation and air temperature data from one of the landfills with onsite meteorological station were used for analysis. In this investigation only two landfills provided temperature and precipitation data. Among these two landfills, the landfill which recorded all relevant parameters (temperature, type and amount of precipitation, concentration of $\mathrm{COD}$ and $\mathrm{NH}_{4}-\mathrm{N}$ ), and had a more extensive dataset ( $\mathrm{n}=1971$ ) was considered for analysis. Moreover, onsite precipitation data from this landfill was also tested against secondary data from one of the nearby DWD-stations (Deutsche Wetterdienst/Germany’s National Meteorological Services) to evaluate the possibility of 
using secondary data from DWD for landfills lacking meteorological data. The selected station from DWD was $16 \mathrm{~km}$ away from the selected landfill (named "landfill with meteorological station" throughout this study) (DWD, 2016), and values from DWD station were 40 to $50 \%$ below the onsite measurement (see appendix). This underestimation in measurement is possibly due to the distance between the two stations and/or type of recording instruments. However, since precipitation trends are similar among both landfills, while differences in specific measurements are quite significant, data from DWD were only used to correlate changes in concentration of COD and $\mathrm{NH}_{4}-\mathrm{N}$ with respect to changes in precipitation and temperature.

Correlations of $\mathrm{COD}$ and $\mathrm{NH}_{4}-\mathrm{N}$ with temperature and precipitation for landfill with meteorological station and landfill C (located less than $10 \mathrm{~km}$ from one of the DWD-stations) are shown in Table 3. According to the table, an increase in monthly ambient temperature corresponds to an increase in monthly COD and $\mathrm{NH}_{4}-\mathrm{N}$ concentrations in both landfills. However, unlike ambient temperature, which shows consistent positive correlation with $\mathrm{COD}$ and $\mathrm{NH}_{4}-\mathrm{N}$ concentrations, the effect of precipitation on these two contaminants is not consistent.

\section{Table 3}

Correlation coefficients of $\mathrm{COD}$ and $\mathrm{NH}_{4}-\mathrm{N}$ with ambient temperature, precipitation, leachate temperature, $\mathrm{EC}$, and $\mathrm{pH}$.

\begin{tabular}{llllll}
\hline Parameter & \multicolumn{2}{l}{ Landfill C } & & & \multicolumn{2}{l}{ Landfill with meteorological station } \\
\cline { 2 - 3 } \cline { 5 - 6 } & $\mathrm{COD}$ & $\mathrm{NH}_{4}-\mathrm{N}$ & & COD & $\mathrm{NH}_{4}-\mathrm{N}$ \\
Electrical conductivity $(\mu \mathrm{S} / \mathrm{cm})$ & 0.85 & 0.82 & & - & - \\
$\mathrm{pH}(-)$ & 0.34 & 0.08 & & - & - \\
Air temperature $\left({ }^{\circ} \mathrm{C}\right)$ & 0.37 & 0.22 & & 0.67 & 0.19 \\
Precipitation $(\mathrm{mm})$ & 0.08 & -0.06 & & 0.08 & -0.22 \\
Leachate temperature $\left({ }^{\circ} \mathrm{C}\right)$ & 0.31 & 0.16 & & - & - \\
\hline
\end{tabular}

Since in landfill C, $\mathrm{COD}$ and $\mathrm{NH}_{4}-\mathrm{N}$ were highly correlated with electrical conductivity (EC), it was also desired to evaluate whether variation in $\mathrm{COD}$ and $\mathrm{NH}_{4}-\mathrm{N}$ concentrations could be predicted using inline EC measurement. To predict COD and $\mathrm{NH}_{4}-\mathrm{N}$ values based on EC measurements, data from landfill C were used to develop a linear regression model. Landfill C was selected for this step due to the more extensive dataset for $\mathrm{EC}, \mathrm{COD}$, and $\mathrm{NH}_{4}-\mathrm{N}$ compared to the other landfills. The equations derived from Landfill $\mathrm{C}$ data were then tested on three other landfills which reported the required 
parameters during 2010 to 2015, and average errors derived from estimation of COD and $\mathrm{NH}_{4}-\mathrm{N}$ in these landfills were then included in the equation (instead of the standard error of the equation itself). Both COD and $\mathrm{NH}_{4}-\mathrm{N}$ equations were highly significant $(p$-value $<0.001)$ and showed $\mathrm{R}^{2}$ values of 0.73 and 0.67 , respectively.

The results of estimation using these equations are shown in Fig. 6; the estimated values of COD and $\mathrm{NH}_{4}-\mathrm{N}$ in landfill $\mathrm{B}$ are very close to real values; however in landfill $\mathrm{E}$ and $\mathrm{F}$, the predicted value is slightly over estimated. The average estimation errors for COD and $\mathrm{NH}_{4}-\mathrm{N}$ were $175 \mathrm{mg} / \mathrm{L}$ and 130 $\mathrm{mg} / \mathrm{L}$ respectively; by considering these errors, two equations of COD $=(-136+0.176$ EC $) \pm 175$ and $\mathrm{NH}_{4}-\mathrm{N}=(-84+0.07$ EC) \pm 130 are proposed. Differences between real and predicted values estimation may be reduced if other parameters such as temperature, precipitation, and $\mathrm{pH}$ value are also considered. Reliable prediction of $\mathrm{COD}$ and $\mathrm{NH}_{4}-\mathrm{N}$ by EC is appealing to operators as a time and cost saving method, and may be used to alert an operator if there are sudden changes in concentration of these two parameters. Another benefit is the correction of existing data, or estimation of missing data; this is revealed through case 20 (landfill B), in which identical values of $1420 \mathrm{mg} / \mathrm{L}$ were reported by the operator for both $\mathrm{COD}$ and $\mathrm{NH}_{4}-\mathrm{N}$. By considering typical outlier detection methods (i.e. observations greater than 1.5 interquartile ranges from upper quartile, which in the case of $\mathrm{NH}_{4}-\mathrm{N}$ refers to values greater than $850 \mathrm{mg} / \mathrm{L}$ ), a value of $1420 \mathrm{mg} / \mathrm{L}$ is an outlier in the $\mathrm{NH}_{4}-\mathrm{N}$ data series. However, rather than disregarding this $\mathrm{NH}_{4}-\mathrm{N}$ sample, the value of which could represent a simple error in data entry (i.e. COD value entered for $\mathrm{NH}_{4}-\mathrm{N}$ as well); it may be replaced by the estimated value of $470 \mathrm{mg} / \mathrm{L}$. 


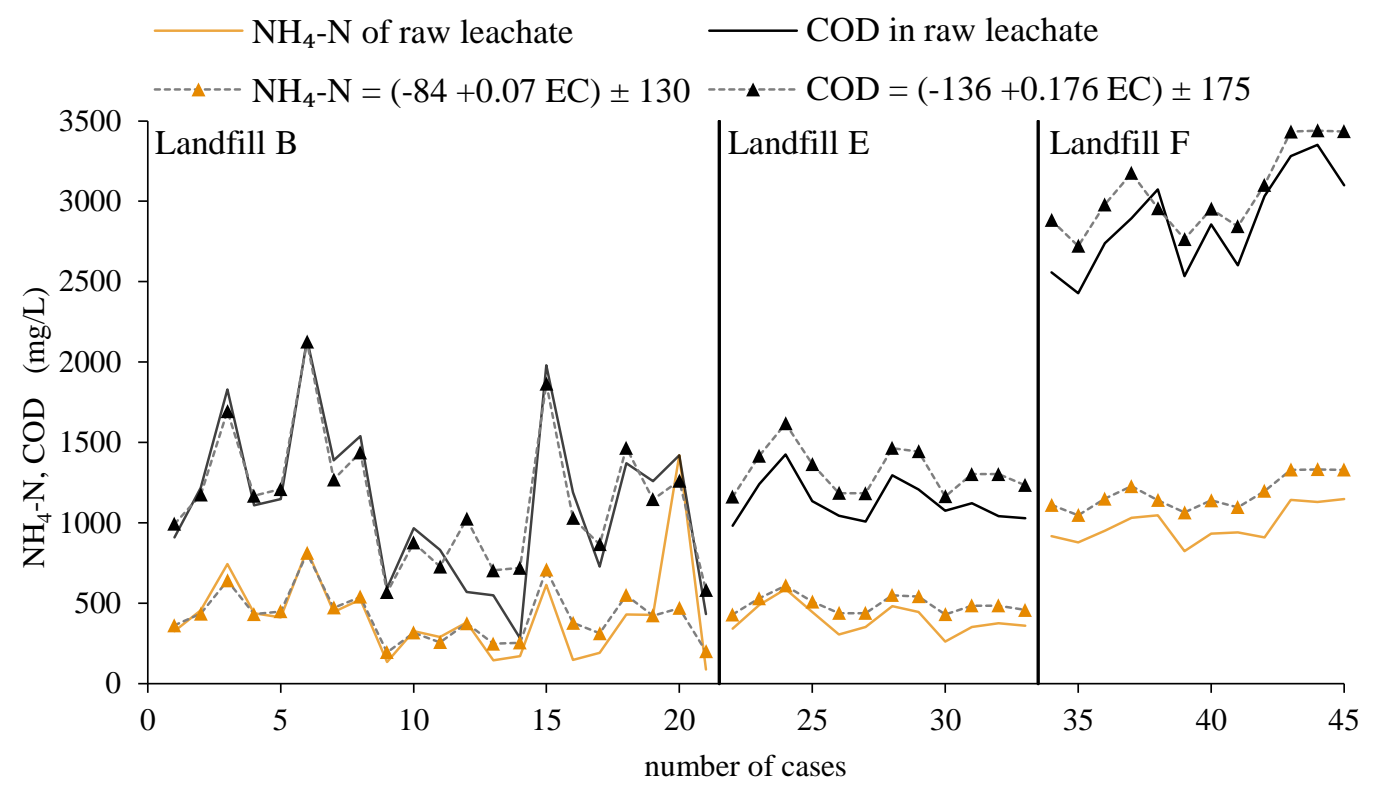

Fig. 6. Estimated $\mathrm{COD}$ and $\mathrm{NH}_{4}-\mathrm{N}$ based on electrical conductivity.

\subsection{Leachate treatment}

Contaminants of concern for leachate treatment are those which demonstrate maximum concentration or 95th percentile values (depending on sample size, this may be used to minimize the effect of outliers) that exceed direct discharge values. According to Table 4, nearly half of contaminants, including many inorganic pollutants (e.g. heavy metals) are below direct discharge limits; among those exceeding the limits are mainly organic substances (COD, BOD, and AOX) and nitrogen (mainly $\mathrm{NH}_{4}-\mathrm{N}$ and $\mathrm{NO}_{3}-\mathrm{N}$ ).

Such leachate characteristics show that existing leachate treatment facilities are inefficient in terms of organic and nitrogen removal, unless they are reconstructed or highly optimized. $\mathrm{BOD}_{5} / \mathrm{COD}$ ratios of leachate from 16 landfills range between 0.017 to 0.167 , with an average and median value of 0.07 and 0.05 respectively. Due to the low leachate biodegradability from these relatively stabilized landfills, an external carbon source is often added (e.g. methanol for completion of denitrification process) alongside customized aeration systems (as aeration is used mainly for oxidation of ammonium to nitrate, not for organics). Under this condition, and also depending on volume of leachate and flexibility of existing system, an operator is limited to four options: 1) improving the leachate characteristics for example through dilution or concentration with imported leachate from 
other landfills, or other streams with higher $\mathrm{BOD}_{5}, 2$ ) closing the existing system and sending the leachate for external treatment, especially in the case of low leachate volumes, 3) either the acquisition, or rent/lease of containerized MBR-plant designed to handle the current leachate pollution load (terms differ depending on duration of agreement and liabilities such as maintenance cost, etc.), or 4) to upgrade an existing plant with deammonification processes. Based on current leachate composition option 4 is the most sustainable decision and has the highest potential to become a common approach among landfills. To this end, feasibility of retrofitting an existing aeration basin with deammonification processes is briefly discussed in the next section.

Table 4

Concentration of current leachate contaminants with respect to limit for direct discharge.

\begin{tabular}{|c|c|c|c|c|c|c|c|c|c|}
\hline \multirow[t]{3}{*}{ Parameter } & \multirow{3}{*}{$\begin{array}{l}\text { Min } \\
(\mathrm{mg} / \mathrm{L})\end{array}$} & \multirow{3}{*}{$\begin{array}{l}\text { Max } \\
\text { (mg/L) }\end{array}$} & \multirow{3}{*}{$\begin{array}{l}95 \text { th } \\
\text { Percentile } \\
(\mathrm{mg} / \mathrm{L})\end{array}$} & \multirow{3}{*}{$\begin{array}{l}\text { mean } \\
\text { (mg/L) }\end{array}$} & \multirow{3}{*}{$\begin{array}{l}\text { Weighted } \\
\text { average } \\
(\mathrm{mg} / \mathrm{L})\end{array}$} & \multirow{2}{*}{\multicolumn{2}{|c|}{$\begin{array}{l}\text { Number of } \\
\text { samples }\end{array}$}} & \multirow{3}{*}{$\begin{array}{l}\text { Number of } \\
\text { Landfills }^{\text {a }}\end{array}$} & \multirow{3}{*}{$\begin{array}{l}\text { discharge } \\
\text { limit }^{\text {b }} \\
(\mathrm{mg} / \mathrm{L})\end{array}$} \\
\hline & & & & & & & & & \\
\hline & & & & & & monthly & total & & \\
\hline Mercury & 0 & 0.013 & 0.003 & 0.001 & 0.001 & 51 & 51 & 3 & 0.05 \\
\hline Cadmium & 0 & 1 & 0.374 & 0.01 & 0.04 & 51 & 51 & 3 & 0.1 \\
\hline Total Chromium & 0.05 & 0.542 & 0.376 & 0.2 & 0.18 & 50 & 50 & 2 & 0.5 \\
\hline Chromium VI & 0.007 & 0.05 & - & 0.0285 & 0.0285 & 2 & 2 & 2 & 0.1 \\
\hline Nickel & 0 & 0.22 & 0.196 & 0.14 & 0.11 & 48 & 48 & 3 & 1 \\
\hline Lead & 0 & 4.1 & 0.05 & 0.05 & 0.1 & 51 & 51 & 3 & 0.5 \\
\hline Copper & 0 & 0.22 & 0.204 & 0.085 & 0.1 & 51 & 51 & 3 & 0.5 \\
\hline Arsenic & 0.023 & 0.05 & - & 0.03 & 0.03 & 5 & 5 & 2 & 0.1 \\
\hline Zinc & 0 & 0.75 & 0.38 & 0.17 & 0.17 & 51 & 51 & 3 & 2 \\
\hline Cyanide & 0.01 & 0.05 & - & 0.03 & 0.03 & 6 & 6 & 3 & 0.2 \\
\hline (easily released) & & & & & & & & & \\
\hline AOX & 0.07 & 3 & 1.5 & 0.96 & 0.68 & 93 & 93 & 14 & 0.5 \\
\hline COD & 280 & 5600 & 4017 & 1732 & 1846 & 201 & 1451 & 25 & 200 \\
\hline $\mathrm{BOD}_{5}$ & 8 & 500 & 209 & 118 & 117 & 124 & 306 & 18 & 20 \\
\hline Total phosphorus & 1.1 & 37.8 & 13.5 & 7.7 & 6.5 & 65 & 139 & 13 & 3 \\
\hline Ammonium $\left(\mathrm{NH}_{4}-\mathrm{N}\right)$ & 89 & 1843 & 1256 & 620 & 637 & 208 & 1223 & 25 & - \\
\hline Nitrite $\left(\mathrm{NO}_{2}-\mathrm{N}\right)$ & 0 & 53 & 13 & 4 & 3 & 141 & 1063 & 6 & - \\
\hline Nitrate $\left(\mathrm{NO}_{3}-\mathrm{N}\right)$ & 0 & 200 & 124 & 30 & 38 & 145 & 1068 & 8 & - \\
\hline Total Nitrogen (TN) & & & & & & & & & 70 \\
\hline
\end{tabular}

${ }^{\mathrm{b}}$ Limit for direct discharge (Anhang-51, 1996). 


\subsection{Deammonification and future opportunities}

To assess feasibility of implementing deammonification, willingness of operators to invest, type of existing leachate treatment process (e.g. sequencing batch reactor (SBR) or conventional nitrification/denitrification (N/DN)), and leachate characteristics (which reveal the risk of inhibition to the anaerobic ammonium-oxidizing bacteria (AnAOB)) are three critical factors to be considered. Hagen (2014) recently investigated variations in landfill leachate treatment processes in Germany and concluded that many treatment systems are dated back to 1990s, and in most cases operators prefer not to change to a new technology but rather to optimize the existing system. From this study it is shown that implementation of deammonification methods in current leachate treatment systems may be practical through retrofitting an existing system.

Table 5 shows a comparison of average nitrogen removal costs by N/DN, magnesium ammonium phosphate (MAP) precipitation, deammonification (single-stage moving bed bioreactor, or MBBR configuration), and deammonification with post-denitrification. Treatment cost is estimated based on the following assumptions: leachate influent characteristics of $\mathrm{NH}_{4}-\mathrm{N}=637 \mathrm{mg} / \mathrm{L} ; \mathrm{NO}_{3}-\mathrm{N}=38 \mathrm{mg} / \mathrm{L}$; $\mathrm{BOD}_{5}=117 \mathrm{mg} / \mathrm{L} ; \mathrm{Q}_{\mathrm{y}}=25,550 \mathrm{~m}^{3}$ (greater value between $\mathrm{Q}_{\text {yearly }}$ and extrapolated $\mathrm{Q}_{\text {daily }}, \mathrm{Q}_{\text {weekly }}, \mathrm{Q}_{\text {monthly }}$ values) as typical leachate from a German landfill. Anaerobic ammonium oxidation (Anammox) stoichiometry was used based on Strous et al. (Strous et al., 1998), and complete ammonium removal was assumed during the deammonification process (in practice, depending on configuration, some $\mathrm{NH}_{4}-\mathrm{N}$ remains in effluent (Lackner et al., 2014), usually below $20 \%$ of incoming $\mathrm{NH}_{4}-\mathrm{N}$ ). Specific energy consumption values of $1.5 \mathrm{kWh} / \mathrm{kg} \mathrm{NH}_{4}-\mathrm{N}$ (Christensson et al., 2013) and $4.2 \mathrm{kWh} / \mathrm{kg} \mathrm{NH}_{4}-\mathrm{N}$ (obtained from a German leachate treatment plant) were used for deammonification and nitrification, respectively. The average cost of electricity was assumed as $0.24 € / \mathrm{kWh}$. Associated costs with postdenitrification of nitrate $\left(\mathrm{NO}_{3}-\mathrm{N}\right.$ of raw leachate and $\mathrm{NO}_{3}-\mathrm{N}$ formed during deammonification) was calculated by considering methanol as external carbon source, a dosing ratio of 5:1 (kgCOD: $\mathrm{kgNO}_{3}{ }^{-}$ N) (ATV-DVWK Standard, 2000) and at a cost of $€ 275$ per metric ton (valid for the first quarter of the year 2016) (Methanex, 2016). Average standard aeration efficiency (SAE) of $3.2 \mathrm{~kg} / \mathrm{kWh}$ (for circulation and aeration) (DWA-Regelwerk, 2015) and release of $2.9 \mathrm{mg}$ of $\mathrm{O}_{2}$ per $1 \mathrm{mg}$ of $\mathrm{NO}_{3}-\mathrm{N}$ 
during denitrification (ATV-DVWK Standard, 2000) was also considered to deduct the recovered energy (during denitrification) from total energy demand. For MAP precipitation, a stoichiometric ratio of 1:1:1 was used. Costs for magnesium chloride $\left(\mathrm{MgCl}_{2} \cdot 6 \mathrm{H}_{2} \mathrm{O}\right)$ and phosphate were considered as $0.22 € / \mathrm{kg}$ and $0.67 € / \mathrm{kg}$ respectively. Market value and suggested market price for struvite varies among countries and different studies (Doyle and Parsons, 2002); in this study a market price of 70 €/MT (from AirPrex® Process) (Ewert and Wagenbach, 2014) was assumed to be deducted from total treatment cost. Moreover, alternatives were only compared based on major contributors to operating expenses, therefore, other associated costs such as sludge dewatering and disposal, further $\mathrm{pH}$ adjustment (for MAP precipitation), costs of carrier material and license fees (for deammonification) were not considered in the analysis.

Table 5

Average nitrogen removal costs by different methods.

\begin{tabular}{|c|c|c|c|c|c|c|c|}
\hline Nitrogen removal & energy & energy & external carbon & chemical & Specific treatm & cost & Total treatment \\
\hline methods & $(\mathrm{kWh} / \mathrm{y})$ & $(€ / y)$ & $(€ / y)$ & $(€ / y)$ & $\left(€ / \mathrm{kg} \mathrm{NH}_{4}-\mathrm{N}\right)$ & $(€ /$ kg N) & $(€)$ \\
\hline MAP & - & - & - & 60955 & 2.8 & - & 45449 \\
\hline Nitrification & 68355 & 16405 & - & - & 1 & - & 16405 \\
\hline $\mathrm{DN} / \mathrm{N}$ & 52726 & 12654 & 22892 & - & - & 2.06 & 35546 \\
\hline Deammonification & 24413 & 5859 & - & - & 0.36 & - & 5859 \\
\hline Deammonification/DN & 24413 & 5859 & 3843 & - & - & 0.56 & 9702 \\
\hline
\end{tabular}

As seen in Table 5, MAP precipitation is the least favorable option for ammonium removal from leachate; this is due to presence of competing calcium ions (Le Corre et al., 2005), and low concentrations of magnesium (125 mg/L) and especially phosphorous $(7 \mathrm{mg} / \mathrm{L})$ in raw leachate, which requires addition of magnesium and phosphorous salts at quantities of 17,964 kg/y and 85,709 kg/y respectively. Deammonification with post-denitrification is promising; when compared to conventional DN/N it results in annual savings of about $€ 25,850$, mostly as a result of reduced carbon dosing demand.

Although economic and technical feasibility may justify retrofitting an existing system with the deammonification process, other factors such as treatment goals, operator knowledge and experience, 
as well as perceived risk (Huijts et al., 2012) also influence the level of acceptance. Treatment goals may be divided into two categories; at global level (e.g. United Nations sustainable development goals) and at individual level (e.g. energy management improvement for single site). Global goals refer to the part of seventh goal of the 2030 agenda for sustainable development (UN-SDGs), in which United Nations propose that the global rate of improvement in energy efficiency should be doubled by 2030 (United-Nations, 2015). In the case of deammonification, the average annual energy savings potential per plant compared to conventional nitrification-denitrification is about $54 \%(28,313$ $\mathrm{kWh} / \mathrm{y}$ ). If we consider an average annual power consumption of $3500 \mathrm{kWh}$ for a three-person household in Germany (BDEW, 2015) and a specific carbon dioxide emission of $560 \mathrm{~g} \mathrm{CO}_{2, \mathrm{eq}} / \mathrm{kWh}$ (UBA, 2016). Based on these considerations, the potential electrical energy savings by retrofitting an existing leachate treatment plant with deammonification will be equal to annual electricity demand of 8 households, and a reduction of 15,855 kg $\mathrm{CO}_{2, \text { eq }}$ per year, per plant.

Operator experience may also be a determining factor in the level of acceptance for upgrading an existing system (Huijts et al., 2012) with deammonification technologies. For example, a reduction in external carbon source addition (e.g. methanol) is an advantage of deammonification process; thus, operator experience with respect to methanol price fluctuations will in large part determine the relative weight placed on this factor. Methanol prices are mainly tied to natural gas prices in Europe (Masih et al., 2010); by considering average costs of methanol in 2010 (254 €/MT) and 2014 (384 €/MT) (Methanex, 2015) and the typical leachate characteristics from 2010 to 2015, the increase of $130 € / M T$ from 2010 compared to 2014 would increase operational costs in 2014 by $€ 10,821$ for conventional nitrification-denitrification.

Perceived risks also affect the level of acceptance of a new energy technology (Huijts et al., 2012); in this case the perceived risks associated with the deammonification process are mainly related to slow growth of anammox bacteria as well as establishment and control of partial nitritation processes. Anammox bacteria have a maximum doubling time of 11 days in batch tests (Strous et al., 1998); recently a much lower maximum specific growth rate of 0.334 per day was reported by Lotti et al (2015). However, in full scale applications the doubling time is much longer and varies greatly based 
on feed temperature (Laureni et al., 2015). Long doubling times of anammox bacteria make reactor start-up and recovery challenging. The process may be inhibited through loss of anammox bacteria (due to poor retention or production of active biomass), substrate concentration, leachate contaminants, and/or operating conditions. As in MBBR configurations, anammox bacteria grow on carrier media and are buffered against system disturbances to some extent by a protective layer of ammonium oxidizing bacteria, which prevent direct contact between annamox bacteria and the bulk liquid medium. To evaluate to what extent anammox activity is affected by contaminants in the leachate, the maximum contaminant concentrations (Fig. 3) were reviewed against minimum threshold values reported to inhibit anammox bacteria.

Depending on type of anammox species (Jetten et al., 2001; Kartal et al., 2007; Schmid et al., 2005), inhibition may occur due to several factors, including salinity, heavy metals, residual substrates (e.g. excess ammonium and nitrite), organic matter, $\mathrm{pH}$, and temperature. Salinity in leachate treatment plants in Germany is reported in terms of electrical conductivity (at $25^{\circ} \mathrm{C}$ ); however most reviewed studies measured the inhibitory effect of salinity based on total dissolved solids (TDS) concentration. Since number of reported ionic species varies among landfills, then estimation of total salinity in terms of TDS (by applying conversion factor, or through summation of major dissolved ions) was not feasible. However by referring to maximum value of major inorganics (maximum value, in mg/L: $\mathrm{Cl}=3000, \mathrm{SO}_{4}=2100, \mathrm{Na}=1800, \mathrm{~K}=1100, \mathrm{Ca}=360, \mathrm{Mg}=170$ ) and heavy metals (maximum value, in $\mathrm{mg} / \mathrm{L}: \mathrm{Pb}=4.1, \mathrm{Mn}=1.1, \mathrm{Cd}=1$, other heavy metals $<1$ ) in the leachate, and considering the inhibitory effect of these contaminants on anammox bacteria (Bi et al., 2014; Dapena-Mora et al., 2007; DapenaMora et al., 2010; Huang et al., 2014), then salinity and concentration of heavy metals are most likely to be below the minimum threshold for inhibition. However some of these substances should still be present at low concentrations, to prevent nutrient starvation for anammox bacteria (Zhang et al., 2016b).

Nutrient requirements depend on microbial cell physiology (Metcalf \& Eddy Inc, 2003). In general, the nutrients required to support microbial growth in wastewater treatment are classified as principal inorganic nutrients (P, K, Mg, Ca, Fe, Na, Cl) (Metcalf \& Eddy Inc, 2003) and minor nutrients (Zn, 
Mn, Cu, Ni) (Madigan et al., 2000). Multiple approaches for anammox enrichment have demonstrated the importance of calcium, magnesium, phosphorous and iron concentrations (Van de Graaf et al., 1996; Van der Star et al., 2008). These nutrients typically exist at sufficient levels in raw leachate, however as typical concentration of total phosphorous (6.5 to $7.7 \mathrm{mg} / \mathrm{L})$ and total iron (6 to $7 \mathrm{mg} / \mathrm{L})$ are close to enrichment concentration ( 0.18 to $0.20 \mathrm{mM}$ or 5.7 to $6.2 \mathrm{mg} \mathrm{P} / \mathrm{L}$ ) (Van de Graaf et al., 1996; Van der Star et al., 2008) and optimum concentration (0.09 mM or $5 \mathrm{mg} / \mathrm{L}$ ) (Liu and Ni, 2015) respectively, their deficiencies as a result of dilution may be a concern during rainy season. Similar to the role of macronutrients, adequate concentrations of micronutrients are required to promote anammox bacterial growth. Micronutrients are often required at concentrations of less than $1 \mathrm{mg} / \mathrm{L}$, making it difficult to establish accurate minimum values (Burgess et al., 1999). Current leachate displays average and maximum concentrations of several micronutrients below 0.2 and $1 \mathrm{mg} / \mathrm{L}$ respectively. It is thus necessary to ensure that bacterial demands for specific micronutrients, even trace amounts, are satisfied.

Another important factor to consider when implementing the deammonification process is the need for control in order to handle changes in concentration of different forms of inorganic nitrogen $\left(\mathrm{NH}_{4}-\mathrm{N}\right.$, $\mathrm{NO}_{2}-\mathrm{N}$, and $\mathrm{NO}_{3}-\mathrm{N}$ ) in raw leachate and also the deammonification process itself. Ammonium and nitrite are essential substrates in the deammonification process; however, when their concentrations exceed certain levels they inhibit the process. As concentration of nitrite in raw leachate is mostly negligible (typically below $13 \mathrm{mg} / \mathrm{L}$ ) then risk of increase in $\mathrm{NO}_{2}-\mathrm{N}$ concentration is due only to the disturbance of anammox populations and/or excessive $\mathrm{NH}_{4}-\mathrm{N}$ oxidation (Lackner et al., 2014). Unlike nitrite, nitrate buildup is not crucial in terms of inhibition effects (Lackner et al., 2014), since its fluctuation range in most extreme cases (about $120 \mathrm{mg} / \mathrm{L}$ in a week) still remains far below the inhibitory range (Dapena-Mora et al., 2007; Strous et al., 1999). However, monitoring fluctuation ranges of nitrate in raw leachate and distinguishing it from the deammonification process is important, to avoid the attribution of nitrate buildup to unrelated phenomena, such as over-aeration during partial nitritation processes. 
Presence of certain organic matter in leachate also affects anammox bacteria; firstly through lack of substrate affinity which results in inhibition of anammox bacteria, secondly through stimulation of growth of heterotrophic bacteria (which may outcompete anammox bacteria) (Zhang et al., 2016a), and lastly by metabolic pathway conversion (Jin et al., 2012) in which anammox bacteria use organics (rather than ammonium and nitrite) as substrate (Güven et al., 2005). Unlike inhibition due to organic substances such as methanol and ethanol which are reported through several studies (Güven et al., 2005; Isaka et al., 2008; Oshiki et al., 2011), inhibition due to COD of raw leachate and formed organics (e.g. AOX) is not widely reported. This may be due to low $\mathrm{BOD}_{5} / \mathrm{COD}$ ratios in leachate, which signifies that most of the organics are mainly humic and fulvic like compounds (Kjeldsen et al., 2002); since these compounds are not biologically degradable, they have no negative effect on anammox bacteria. One method to mitigate organics inhibition is to remove them prior to the deammonification process by chemical precipitation. Lime, alum, and ferric coagulants are typically used for biologically pre-treated leachate or mature leachate treatment (Forgie, 1988), resulting in 50 to $60 \%$ COD reduction (Amokrane et al., 1997). However, among these coagulants, alum is the least desirable, as it has lower removal efficiency compared to iron salts (Renou et al., 2008) and its application is limited depending on downstream treatment processes. For example many German landfills with direct discharge of leachate are equipped with reverse osmosis technologies (RO) (Hagen, 2014) which hinder application of aluminum salts, as residues (due to their high solubility) may cause mineral fouling on RO surfaces (Voutchkov, 2010).

Control of temperature, $\mathrm{pH}$, and dissolved oxygen (DO) is also essential to maintain anammox bacteria in the system (Jin et al., 2012). According to data from 6 landfills, monthly leachate temperature varies between $8{ }^{\circ} \mathrm{C}$ to $25^{\circ} \mathrm{C}$. Since the maximum temperature is lower than or equal to the optimum growing temperatures for different type of anammox species (Jetten et al., 2001; Kartal et al., 2007; Schmid et al., 2005) (e.g. $37^{\circ} \mathrm{C}$ for Ca. Brocadia and Ca. Jettenia, and $25{ }^{\circ} \mathrm{C}$ for Ca. Scalindua (Ali and Okabe, 2015)), then gradual increase in leachate temperature over months is not a concern. However, steep drops in leachate temperature lower anammox activity (e.g. nitrogen removal rate) and growth rates (Lackner et al., 2014; Laureni et al., 2015). As a rule of thumb biochemical 
reaction rates (and growth rates) double for every $10{ }^{\circ} \mathrm{C}$ increase in temperature (up to optimum growth temperature) (Jantrania and Gross, 2006). To identify in which months of the year the leachate temperature lies above $20^{\circ} \mathrm{C}$ and below $10{ }^{\circ} \mathrm{C}$, three landfills with plentiful leachate temperature data ( $\mathrm{n}=788$ ) were considered. Temperatures above $20^{\circ} \mathrm{C}$ were observed from May to October and in most cases in July and August, while temperatures below $10{ }^{\circ} \mathrm{C}$ occurred during November to April, and for most of February. Maximum daily fluctuations of leachate temperature in these three landfills were +8 ${ }^{\circ} \mathrm{C}\left(12{ }^{\circ} \mathrm{C}\right.$ to $\left.20^{\circ} \mathrm{C}\right)$ and $-5{ }^{\circ} \mathrm{C}\left(18^{\circ} \mathrm{C}\right.$ to $\left.13^{\circ} \mathrm{C}\right)$. Since sudden changes in influent temperatures (e.g. 8 ${ }^{\circ} \mathrm{C}$ in a week) influence performance of anammox based technologies (Lackner et al., 2014), control of input leachate temperature is important. Two possible methods for temperature change mitigation are the covering of aeration tanks and the utilization of exhaust heat from air supply blowers (Stegmann et al., 2005).

Regular monitoring and control of $\mathrm{pH}$ is also important, especially in plants where high $\mathrm{pH}$ fluctuation is expected (Lackner et al., 2014); however, in current landfills the $\mathrm{pH}$ value typically remains relatively stable. Physiological pH range for anammox bacteria is reported to be 6.7 to 8.3 (Strous et al., 1999); full scale plants operate at $\mathrm{pH}$ values between 6.8 and 8. Exceedance of lower and upper limit results in inhibition of ammonium oxidizing bacteria and anammox bacteria respectively (Lackner et al., 2014). The range of leachate $\mathrm{pH}$ values from 8 German landfills ( $\mathrm{n}=839$ ) was between 7.4 to 8.3; both expected value and weighted average (based on logarithmic transformation) of $\mathrm{pH}$ among these landfills were 7.8. As during the deammonification process $\mathrm{pH}$ is slightly increased, $\mathrm{pH}$ control through acid addition may also be necessary.

\section{Conclusion}

Pre-treatment of waste results in more homogenous leachate quality among landfills, and lower concentrations of biodegradable organic matter and heavy metals in the leachate. The reduced biological oxygen demand $\left(\mathrm{BOD}_{5}\right)$ and heavy metal concentrations present in current leachate favors the condition of retrofitting exiting biological reactor(s) with deammonification process. Considering average leachate characteristics of German landfills, there is an annual savings potential of about 
$€ 25850$ (in terms of energy and external carbon source) by retrofitting with deammonification process and post denitrification. Moreover, as concentration of most of heavy metals are below $1 \mathrm{mg} / \mathrm{L}$, and concentration of major salt ions $(\mathrm{Na}, \mathrm{Cl}, \mathrm{K})$ and $\mathrm{BOD}_{5}$ are lower than inhibition thresholds, inhibition due to leachate contaminants is not a concern. However, control of operating conditions (mainly temperature) may be important.

\section{Acknowledgment}

This research was funded in part by Deutscher Akademischer Austauschdienst (DAAD) and the Bundesministerium für Bildung und Forschung (BMBF). The authors wish to thank Yvonne Schneider for providing valuable comments on draft version of this paper.

\section{Appendix A. supplementary material}

\section{References}

Ali, M., Okabe, S., 2015. Anammox-based technologies for nitrogen removal: advances in process start-up and remaining issues. Chemosphere 141, 144-153.

http://dx.doi.org/10.1016/j.chemosphere.2015.06.094.

Amokrane, A., Comel, C., Veron, J., 1997. Landfill leachates pretreatment by coagulationflocculation. Water Res. 31, 2775-2782. http://dx.doi.org/10.1016/S0043-1354(97)00147-4. Anhang-51, 1996. Oberirdische Ablagerung von Abfällen. Allgemeine Rahmen-Verwaltungsvorschrift über Mindestanforderungen an das Einleiten von Abwasser in Gewässer.

ATV-DVWK Standard, 2000. Dimensioning of Single-Stage Activated Sludge Plants. DWA.

Baig, S., Coulomb, I., Courant, P., Liechti, P., 1999. Treatment of landfill leachates: Lapeyrouse and Satrod case studies. Ozone Sci. Eng. 21, 1-22. http://dx.doi.org/10.1080/01919519908547255.

BDEW, 2015. Stromrechnung für Haushalte.

http://www.bdew.de/internet.nsf/id/9D1CF269C1282487C1257E22002BC8DD/\$file/150409\%20BDE W\%20zum\%20Strompreis\%20der\%20Haushalte\%20Anhang.pdf (accessed 09.06.2016). 
Bi, Z., Qiao, S., Zhou, J., Tang, X., Cheng, Y., 2014. Inhibition and recovery of Anammox biomass subjected to short-term exposure of Cd, Ag, Hg and Pb. Chem. Eng. J. 244, 89-96.

http://dx.doi.org/10.1016/j.cej.2014.01.062.

Burgess, J., Quarmby, J., Stephenson, T., 1999. Role of micronutrients in activated sludge-based biotreatment of industrial effluents. Biotechnol. Adv. 17, 49-70. http://dx.doi.org/10.1016/S0734$\underline{9750(98) 00016-0 .}$

Christensson, M., Ekström, S., Chan, A.A., Le Vaillant, E., Lemaire, R., 2013. Experience from startups of the first ANITA Mox plants. Water Sci. Technol. 67, 2677-2684.

http://dx.doi.org/10.2166/wst.2013.156.

Chu, L., Cheung, K., Wong, M., 1994. Variations in the chemical properties of landfill leachate. Environ. Manage. 18, 105-117. http://dx.doi.org/10.1007/BF02393753.

Dapena-Mora, A., Fernandez, I., Campos, J., Mosquera-Corral, A., Mendez, R., Jetten, M., 2007. Evaluation of activity and inhibition effects on Anammox process by batch tests based on the nitrogen gas production. Enzyme Microb. Technol. 40, 859-865.

http://dx.doi.org/10.1016/j.enzmictec.2006.06.018.

Dapena-Mora, A., Vázquez-Padín, J., Campos, J., Mosquera-Corral, A., Jetten, M., Méndez, R., 2010. Monitoring the stability of an Anammox reactor under high salinity conditions. Biochem. Eng. J. 51, 167-171. http://dx.doi.org/10.1016/j.bej.2010.06.014.

Doyle, J.D., Parsons, S.A., 2002. Struvite formation, control and recovery. Water Res. 36, 3925-3940. http://dx.doi.org/10.1016/S0043-1354(02)00126-4.

DWA-Regelwerk, 2015. Arbeitsblatt DWA-A 216, Energiecheck und Energieanalyse Instrumente zur Energieoptimierung von Abwasseranlagen. DWA Deutsche Vereinigung für Wasserwirtschaft, Abwasser und Abfall e. V., Hennef

DWD, 2016. Germany’s National Meteorological Services (Deutsche Wetterdienst) ftp://ftpcdc.dwd.de/ (accessed 29.02.2016).

Ewert, W., Wagenbach, A., 2014. AirPrex: MAP-Kristallisation in Verbindung mit Bio-P-Fällung. http://www.umweltbundesamt.de/sites/default/files/medien/378/dokumente/ewertwagenbach pcs.pdf (accessed 08.03.2016). 
Fitzke, B., Blume, T., Wienands, H., Cambiella, Á., 2013. Hybrid processes for the treatment of leachate from landfills, Economic Sustainability and Environmental Protection in Mediterranean Countries through Clean Manufacturing Methods. Springer, pp. 107-126.

Forgie, D., 1988. Selection of the most appropriate leachate treatment methods. Part 3: A decision model for the treatment train selection. Water Qual. Res. J. Can. 23, 341-355.

Güven, D., Dapena, A., Kartal, B., Schmid, M.C., Maas, B., van de Pas-Schoonen, K., Sozen, S., Mendez, R., den Camp, H.J.O., Jetten, M.S., 2005. Propionate oxidation by and methanol inhibition of anaerobic ammonium-oxidizing bacteria. Appl. Environ. Microbiol. 71, 1066-1071. http://dx.doi.org/10.1128/AEM.71.2.1066-1071.2005.

Hagen, K., 2014. Stand der Technik der Deponiesickerwasserbehandlung. Institut für Siedlungswasserwirtschaft und Abfalltechnik (ISAH), Leibniz Universität Hannover. Heyer, K., Stegmann, R., für Abfallwirtschaft, I., 2001. Leachate management: leachate generation, collection, treatment and costs. http://www.ifas-hamburg.de/pdf/leachate.pdf (accessed 02.11.2014). Hippen, A., Rosenwinkel, K.-H., Baumgarten, G., Seyfried, C.F., 1997. Aerobic deammonification: a new experience in the treatment of wastewaters. Water Sci. Technol. 35, 111-120. http://dx.doi.org/10.1016/S0273-1223(97)00211-4. Huang, X., Gao, D., Peng, S., Tao, Y., 2014. Effects of ferrous and manganese ions on anammox process in sequencing batch biofilm reactors. Journal of Environmental Sciences 26, 1034-1039. http://dx.doi.org/10.1016/S1001-0742(13)60531-8.

Huijts, N.M., Molin, E., Steg, L., 2012. Psychological factors influencing sustainable energy technology acceptance: A review-based comprehensive framework. Renewable and Sustainable Energy Reviews 16, 525-531. http://dx.doi.org/10.1016/j.rser.2011.08.018.

Isaka, K., Suwa, Y., Kimura, Y., Yamagishi, T., Sumino, T., Tsuneda, S., 2008. Anaerobic ammonium oxidation (anammox) irreversibly inhibited by methanol. Appl. Microbiol. Biotechnol. 81, 379-385. http://dx.doi.org/10.1007/s00253-008-1739-0. Jantrania, A.R., Gross, M.A., 2006. Advanced onsite wastewater systems technologies. CRC Press. Jenkins, D., Wanner, J., 2014. Activated Sludge-100 Years and Counting. IWA Publishing. 
Jetten, M.S., Wagner, M., Fuerst, J., van Loosdrecht, M., Kuenen, G., Strous, M., 2001. Microbiology and application of the anaerobic ammonium oxidation ('anammox') process. Curr. Opin. Biotechnol. 12, 283-288. http://dx.doi.org/10.1016/S0958-1669(00)00211-1.

Jin, R.-C., Yang, G.-F., Yu, J.-J., Zheng, P., 2012. The inhibition of the Anammox process: a review. Chem. Eng. J. 197, 67-79. http://dx.doi.org/10.1016/j.cej.2012.05.014.

Kartal, B., Rattray, J., van Niftrik, L.A., van de Vossenberg, J., Schmid, M.C., Webb, R.I., Schouten, S., Fuerst, J.A., Damsté, J.S., Jetten, M.S., 2007. Candidatus “Anammoxoglobus propionicus” a new propionate oxidizing species of anaerobic ammonium oxidizing bacteria. Syst. Appl. Microbiol. 30, 39-49. http://dx.doi.org/10.1016/j.syapm.2006.03.004.

Kjeldsen, P., Barlaz, M.A., Rooker, A.P., Baun, A., Ledin, A., Christensen, T.H., 2002. Present and long-term composition of MSW landfill leachate: a review. Crit. Rev. Environ. Sci. Technol. 32, 297336.

Kruse, K., 1994. Langfristiges emissionsgeschehen von siedlungsabfalldeponien. Institut für Siedlungswasserwirtschaft, TU Braunschweig.

Kumar, D., Alappat, B.J., 2005. Evaluating leachate contamination potential of landfill sites using leachate pollution index. Clean Technologies and Environmental Policy 7, 190-197. http://dx.doi.org/10.1007/s10098-004-0269-4. Lackner, S., Gilbert, E.M., Vlaeminck, S.E., Joss, A., Horn, H., van Loosdrecht, M.C., 2014. Fullscale partial nitritation/anammox experiences-an application survey. Water Res. 55, 292-303. http://dx.doi.org/10.1016/j.watres.2014.02.032.

Laureni, M., Weissbrodt, D.G., Szivák, I., Robin, O., Nielsen, J.L., Morgenroth, E., Joss, A., 2015. Activity and growth of anammox biomass on aerobically pre-treated municipal wastewater. Water Res. 80, 325-336. http://dx.doi.org/10.1016/j.watres.2015.04.026.

Le Corre, K.S., Valsami-Jones, E., Hobbs, P., Parsons, S.A., 2005. Impact of calcium on struvite crystal size, shape and purity. J. Cryst. Growth 283, 514-522.

http://dx.doi.org/10.1016/j.jcrysgro.2005.06.012. 
Liu, Y., Ni, B.-J., 2015. Appropriate Fe (II) addition significantly enhances anaerobic ammonium oxidation (anammox) activity through improving the bacterial growth rate. Scientific reports 5. http://dx.doi.org/10.1038/srep08204.

Lotti, T., Kleerebezem, R., Abelleira-Pereira, J., Abbas, B., van Loosdrecht, M., 2015. Faster through training: the anammox case. Water Res. 81, 261-268. http://dx.doi.org/10.1016/j.watres.2015.06.001. Madigan, M., Martinko, J., Parker, J., 2000. Brock Biology of Microorganisms. Southern Illinois University Carbondale. Prentice Hall International, Inc.

Masih, A.M.M., Albinali, K., DeMello, L., 2010. Price dynamics of natural gas and the regional methanol markets. Energy Policy 38, 1372-1378. http://dx.doi.org/10.1016/j.enpol.2009.11.018. Metcalf \& Eddy Inc, 2003. Wastewater engineering, treatment and reuse, fourth ed. McGraw-Hill Education.

Methanex, 2015. Methanex Monthly Average Regional Posted Contract Price History. http://www.methanex.com/sites/default/files/methanol-price/MxAvgPrice_Feb\%2027\%202015.pdf (accessed 19.01.2016).

Methanex, 2016. Methanex Methanol Price. http://www.methanex.com/our-business/pricing (accessed 18.03.2016).

Oshiki, M., Shimokawa, M., Fujii, N., Satoh, H., Okabe, S., 2011. Physiological characteristics of the anaerobic ammonium-oxidizing bacterium ‘Candidatus Brocadia sinica’. Microbiology 157, 17061713. http://dx.doi.org/10.1099/mic.0.048595-0.

Renou, S., Givaudan, J., Poulain, S., Dirassouyan, F., Moulin, P., 2008. Landfill leachate treatment: review and opportunity. J. Hazard. Mater. 150, 468-493.

http://dx.doi.org/10.1016/j.jhazmat.2007.09.077.

Rosenwinkel, K.H., Cornelius, A., 2005. Deammonification in the moving-bed process for the treatment of wastewater with high ammonia content. Chemical engineering \& technology 28, 49-52. http://dx.doi.org/10.1002/ceat.200407070.

Salem, Z., Hamouri, K., Djemaa, R., Allia, K., 2008. Evaluation of landfill leachate pollution and treatment. Desalination 220, 108-114. http://dx.doi.org/10.1016/j.desal.2007.01.026. 
Schmid, M.C., Maas, B., Dapena, A., van de Pas-Schoonen, K., van de Vossenberg, J., Kartal, B., Van Niftrik, L., Schmidt, I., Cirpus, I., Kuenen, J.G., 2005. Biomarkers for in situ detection of anaerobic ammonium-oxidizing (anammox) bacteria. Appl. Environ. Microbiol. 71, 1677-1684. http://dx.doi.org/10.1128/AEM.71.4.1677-1684.2005.

Siddiqui, A., Richards, D., Powrie, W., 2012. Investigations into the landfill behaviour of pretreated wastes. Waste Manage. 32, 1420-1426. http://dx.doi.org/10.1016/j.wasman.2012.03.016.

Stegmann, R., Heyer, K., Cossu, R., 2005. Leachate treatment, Proceedings Sardinia.

Strous, M., Heijnen, J., Kuenen, J., Jetten, M., 1998. The sequencing batch reactor as a powerful tool for the study of slowly growing anaerobic ammonium-oxidizing microorganisms. Appl. Microbiol. Biotechnol. 50, 589-596. http://dx.doi.org/10.1007/s002530051340.

Strous, M., Kuenen, J.G., Jetten, M.S., 1999. Key physiology of anaerobic ammonium oxidation. Appl. Environ. Microbiol. 65, 3248-3250.

Tatsi, A., Zouboulis, A., 2002. A field investigation of the quantity and quality of leachate from a municipal solid waste landfill in a Mediterranean climate (Thessaloniki, Greece). Adv. Environ. Res. 6, 207-219. http://dx.doi.org/10.1016/S1093-0191(01)00052-1.

Tran, H.N., Münnich, K., Fricke, K., Harborth, P., 2013. Removal of nitrogen from MBT residues by leachate recirculation in combination with intermittent aeration. Waste Manage. Res., 0734242X13512892. http://dx.doi.org/10.1177/0734242X13512892.

UBA, 2016. Entwicklung der spezifischen Kohlendioxid-Emissionen des deutschen Strommix in den Jahren 1990 bis 2015.

http://www.umweltbundesamt.de/sites/default/files/medien/378/publikationen/climate_change_26_20 16_entwicklung_der_spezifischen_kohlendioxid-emissionen_des_deutschen_strommix.pdf (accessed 09.06.2016).

United-Nations, 2015. Goal 7: Ensure access to affordable, reliable, sustainable and modern energy for all. http://www.un.org/sustainabledevelopment/energy/ (accessed 07.06.2016).

Van de Graaf, A.A., de Bruijn, P., Robertson, L.A., Jetten, M.S., Kuenen, J.G., 1996. Autotrophic growth of anaerobic ammonium-oxidizing micro-organisms in a fluidized bed reactor. Microbiology 142, 2187-2196. http://dx.doi.org/10.1099/13500872-142-8-2187. 
Van der Star, W.R., Miclea, A.I., van Dongen, U.G., Muyzer, G., Picioreanu, C., van Loosdrecht, M., 2008. The membrane bioreactor: a novel tool to grow anammox bacteria as free cells. Biotechnol. Bioeng. 101, 286-294. http://dx.doi.org/10.1002/bit.21891. Voutchkov, N., 2010. Considerations for selection of seawater filtration pretreatment system. Desalination 261, 354-364. http://dx.doi.org/10.1016/j.desal.2010.07.002. WERF, 2014. WERF Nutrient Challenge “Deammonification”. http://www.werf.org (accessed 11.03.2015).

Wiszniowski, J., Robert, D., Surmacz-Gorska, J., Miksch, K., Weber, J., 2006. Landfill leachate treatment methods: A review. Environmental Chemistry Letters 4, 51-61.

Zhang, D., Vahala, R., Wang, Y., Smets, B.F., 2016a. Microbes in biological processes for municipal landfill leachate treatment: Community, function and interaction. Int. Biodeterior. Biodegrad. http://dx.doi.org/10.1016/j.ibiod.2016.02.013.

Zhang, Z.-Z., Zhang, Q.-Q., Xu, J.-J., Deng, R., Ji, Z.-Q., Wu, Y.-H., Jin, R.-C., 2016b. Evaluation of the inhibitory effects of heavy metals on anammox activity: A batch test study. Bioresour. Technol. 200, 208-216. http://dx.doi.org/10.1016/j.biortech.2015.10.035. 